\title{
Nomenclatural validation of the genetically revised cyanobacterial genus Dolichospermum (Ralfs ex Bornet et Flahault) comb. nova
}

\author{
Pirjo WACKLIN ${ }^{1}$, Lucien HofFMANN ${ }^{2} \&$ Jiří KOMÁREK ${ }^{3}$ \\ ${ }^{1}$ Department of Applied Chemrstry and Microbiology Viikki Biocenter, PO Box 56, FI-00014, Unversity of \\ Helsinky, Finland \\ ${ }^{2}$ Départment Environnement et Agro-biotechnologies (EVA), Centre de Recherche Public-Gabriel Lippmann 41, \\ rue du Brill, L-4422 Belvaux, Grand-duchy of Luxembourg \\ ${ }^{3}$ Institute of Botany, Academy of Sciences of the Czech Republic, Dukelská 135, CZ-37982 Třeboñ and Faculty of \\ Science, University of South Bohemia, Branišovská 31, CZ 37005 České Budějovice, Czech Republic
}

\begin{abstract}
The traditional cyanobacterial genus Anabaena is heterogeneous, as follows from the modern molecular evaluation. The cluster of planktic Anabaena-morphotypes with gas vesicles in cells must be separated as a unique generic entity from the typical benthic mat-forming species. In the present articles all planktic morphospecies are transferred into the new genus Dolichospermum in agreement with Botanical nomenclatoric rules. The name "Dolichospermum" is based on a taxonomic category of section in starting point publication (BORNET \& FLAHAULT 1888), which is valid for heterocytous cynobacteria.
\end{abstract}

Key words: Cyanobacteria, Anabaena, Dolichospermum, taxonomy, nomenclatoric validation

\section{Introduction}

The diversity of organisms (both in nature and in culture) can be reviewed and characterised only by help of the taxonomic classification. However, the modern classification of cyanobacteria must be based and revised on the molecular approach, and for the generic delimitation the clustering by $16 \mathrm{~S}$ rRNA gene sequencing is particularly required. The cyanobacterial heterocytous genus Anabaena in traditional sense of BorNET \& FlaHAULT (1888) and Geitler (1932) is heterogeneous. The benthic and soil inhabiting Anabaena-types (forming mats and never producing gas vesicles in cells) were found clearly genetically separated from the planktic cluster containing free-floating solitary trichomes or their small groups, and producing obligatorily reversible gas vesicles in cells (ITEMAN et al. 2002, GUGGer et al. 2002 a,b, RAJANIEMI et al. 2005a,b, WiLlame et al. 2006) (Fig. 1). Gas vesicles production is genetically fixed adaptation to the planktic way of life. Gas vesicles have a special structure and are grouped in cells into aerotopes (= previously "gas vacuoles") recognizable by optical microscopy (WALSBY 1972, 1978, 1981, etc). The genetic difference between planktic and typical mat-forming Anabaena-morphotypes is so distinct that both these clusters must be classified in modern cyanoprocaryotic system as separate genera (GugGer et al. 2002b, HofFMAnN et al. 2005, RAJANIEMI et al. 2005a,b, WiLlame et al. 2006). Because the type species of the genus Anabaena, A. oscillarioides Bory ex Bornet et Flahault 1888 belongs to benthic types, the planktic Anabaena-cluster must be renamed and classified as a special genus. The name "Dolichospermum", which was used in the starting point (BORNET \& Flahault 1888, p. 228) as the valid name for section ("Sectio II - Dolichospermum RALFS 1850 "), can be used as valid generic name for the planktic cluster. This section contains the common planktic species "Anabaena flos-aquae BRÉBISSON ex Bornet et Flahault 1888", which is designated as a type species of the revised genus Dolichospermum (RALFs ex Bornet et Flahault) comb. nova.

\section{Methods}

The results are based on the molecular analyses, mainly on the 16S rRNA gene sequencing, used for the study of planktic Anabaena-species. The methods used are described in detail in ITEMAN et al. (2002), GugGer et al. (2002a, 2002b), RAJANIEMI et al. (2005a, 2005b) and Willame et al. (2006). The rules of botanical nomenclature (Botanical Code) are accepted for the nomenclatoric evaluation and the requests of the validation of modern, revised cyanobacterial taxa (Oren \& Tindal 2005) are respected. 


\section{Results}

Dolichospermum (Ralfs ex Bornet et Flahault) comb. nova

Syn. (basionym): Sectio II - Dolichospermum RalfS 1850 ex Bornet et Flahault, Ann. Sci. Nat. Bot. VII, 7: 228,1888 .

Type species: Dolichospermum flos-aquae ([Lyngbye] Brébisson ex Bornet et Flahault) comb. nova (syn. and basionym: = Anabaena flosaquae [LyngBye] BréBisson ex Bornet et Flahault, Ann. Sci. Nat. Bot. VII, 7: 228, 1888).

Main generic diacritical characters (obligatory for all species):

- The genus Dolichospermum (evaluated by $16 \mathrm{~S}$ rRNA gene sequencing) belongs genetically into the unique cluster of nostocalean heterocytous cyanobacteria.

- This genetically separated group (Dolichospermum) represents a complex cluster, the different members of which do not differ less than in $92 \%$ of $16 \mathrm{~S}$ rRNA gene similarity one from another (see Fig. 1).

- Trichomes are isopolar, metameric with respect to heterocytes position, with constrictions at cross-walls, without firm sheaths, sometimes with fine mucilaginous, diffluent envelopes. The growth of trichomes is theoretically endless.

- Apical cells are morphologically similar to vegetative cells, they are not differentiated and are able to divide.

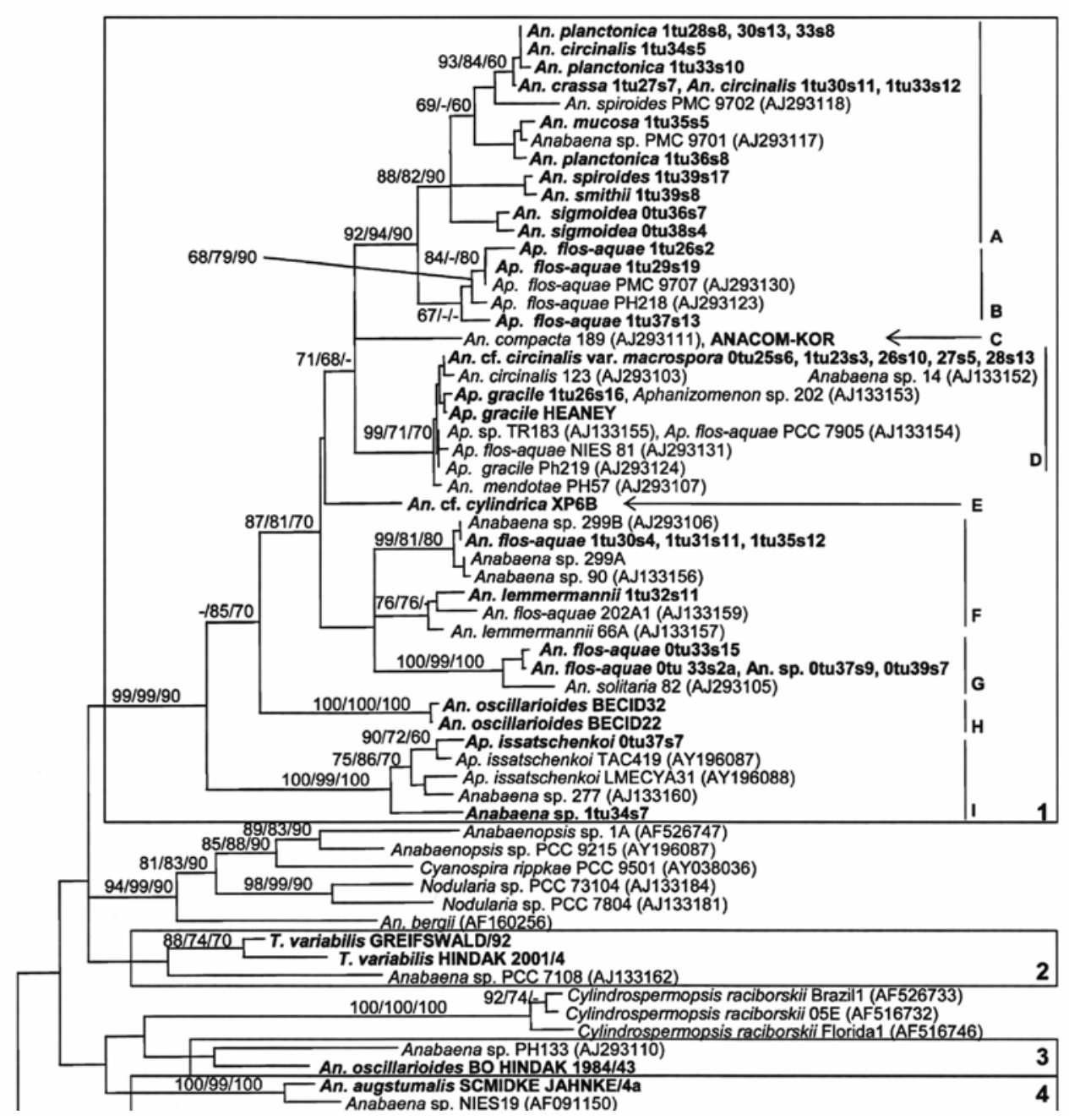

Fig. 1. The molecular evaluation of planktic Anabaena/Aphanizomenon clusters based on the 16S rRNA gene sequencing according to RAJANIEMI et al. (2005a): (B) cluster of typical Aphanizomenon flos-aquae; (H) "Anabaena oscillarioides" (non planktic types); (I) cluster of Aphanizomenon issatschenkoi $=$ Cuspidothrix. The rest of all planktic Anabaenas is also heterogeneous in certain degree, but the morphological features are mostly transient. Their taxonomic classification will be corrected and modified by further studies on basis of Dolichospermum. 
- Gas vesicles occur obligatorily in cells in vegetative phase. They are joined into irregular aerotopes (sooner "gas vesicles") over the whole cell volume; aerotopes are recognizable in cells under optical microscope.

- Heterocytes arise intercalarly, solitary (exceptionally in pairs); they develop from vegetative cells in \pm metameric position.

- Akinetes develop paraheterocytically, it means connected with heterocytes, rarely aside heterocytes from both sides or (more commonly) separated from them by several cells, solitary up to 5(6) in a row. They develop successively in the direction from heterocytes and often arise after fusion of two or few neighbouring vegetative cells. The ripe akinetes are usually three or more-times larger than vegetative cells.

- All species (morphotypes) are planktic in vegetative state, never form sessile mats on the substrate. The filaments live solitary or in small clusters.

Autapomorphic characteristics: Filaments living isolated or in free clusters; metameric structure of trichomes with heterocytes developing solitary; obligatory gas vesicles in vegetative cells; akinetes develop paraheterocytically.

\section{List of species:}

- Dolichospermum affinis (LemmermanN) comb. nova - basionym: Anabaena affinis LEMMERMANN, Abh. Naturw. Ver. Bremen 14: 261, 1897.

- Dolichospermum akankoensis (M. WATANABE) comb. nova - basionym: Anabaena akankoensis M. Watanabe, Bull. Natn. Sci. Mus.,Tokyo, Ser. B, 29: 9-13, 2003.

- Dolichospermum arcticum (KISELEv) comb. nova basionym: Anabaena arctica KISELEv, Gosud. Hidrol. Inst., Issled. Morej SSSR 15: 98, 1932.

- Dolichospermum bituri (CRONBERG et KOMÁREK) comb. nova - basionym: Anabaena bituri Cronberg et KomÁrek, Nova Hedwigia 78: 75, 2004.

- Dolichospermum berezowskii (UsAČEv) comb. nova - basionym: Anabaena berezowskii UsAčEv, Tr. Sibir. Naučn. Ribochoz. Stan. Krasnojarsk 3(2): 32, 1928.

- Dolichospermum bothai (WeLsh) comb. nova basionym: Anabaena bothai WeLsh, Rev. de Biol. 2(3/4): 259-260, 1961

- Dolichospermum caspicum (Ostenfeld) comb. nova - basionym: Anabaena caspica OSTENFELD,
Vidensk. Medd. Naturh. Fören. Kjøbenhavn 1901: 138, 1902.

- Dolichospermum circinalis (RABENHORST ex BoRNET et Flahault) comb. nova - basionym: Anabaena circinalis Rabenhorst ex Bornet et Flahault, Ann. Sci. Nat. 7, Bot 7: 230, 1888.

- Dolichospermum citrisporum (M. Watanabe) comb. nova - basionym: Anabaena citrispora M. Watanabe, Bull. Nat. Sci. Mus., ser. B, 18(4): 124-126, 1992.

- Dolichospermum compactum (NYGAARD) comb. nova - basionym: Anabaena spiroides var. minima f. compacta NygAARD Kong. Danske Vidensk. Selsk., Biol. Skr. 7(1): 205, 1949 [syn.: Anabaena compacta (NYGAARD) Hickel, Algological Studies 38/39: 269, 1985].

- Dolichospermum crassum (Lemmermann) comb. nova - basionym: Anabaena spiroides var. crassa LemMERMANN Bot. Centralbl. 76(5-6): 155, 1898 [syn.: Anabaena crassa (LEMMERMANN) KomÁrková-Legnerová et Cronberg, Algolog. Stud. 67: 24-25, 1992].

- Dolichospermum curvum (HILL) comb. nova basionym: Anabaena curva Hill, Phycologia 15(1): 62, 1976.

- Dolichospermum danicum (NygAARD) comb. nova - basionym: Anabaena viguieri var. danica NygaARD, Kong. Danske Vidensk. Selsk., Biol. Skr. 7(1): 212, 1949 [syn.: Anabaena danica (NygaArd) Komárková-Legnerová et Eloranta, Algolog. Stud. 67: 112, 1992].

- Dolichospermum delicatulum (LemmermanN) comb. nova - basionym: Anabaena delicatula LemmermanN, Bot. Centralbl. 70: 155, 1898

- Dolichospermum ellipsoides (Bolochoncev ex VORONICHIN) comb. nova-basionym: Anabaena ellipsoides Bolochoncev ex Voronichin, Tr. Bot. Sada AN SSSR 44: 221, 1931.

- Dolichospermum fallax (KomÁreK et KomÁrkovÁLEGNEROVÁ) comb. nova-basionym: Anabaena fallax KomÁReK et KomÁRKovÁ-LegnerovÁ, Preslia 74: 223. 2002.

- Dolichospermum farciminiformis (CRONBERG et KomÁrKovÁ-Legnerová) comb. nova basionym: Anabaena farciminiformis CRONBERG et KomÁrková-Legnerová, Algolog. Stud. 5053: 278, 1988.

- Dolichospermum fusca (Hill) comb. nova basionym: Anabaena fusca HiLl, Phycologia 15(1): 70, 1976.

- Dolichospermum halbfassii (BACHMANN) comb. nova - basionym: Anabaena halbfassii BACHMANN, Ber. Dtsch. Bot. Ges. 31: 187, 1913.

- Dolichospermum helicoideum (BERNARD) comb. nova - basionym: Anabaena helicoidea Bernard, Protococc. \& Desmid. d'Eau Douce, p. 52, 1908.

- Dolichospermum heterosporum (NYGAARD) comb. 
nova - basionym: Anabaena heterospora NygaARd, Kong. Danske Vidensk. Selsk., Biol. Skr., 7(1): 195, 1949.

- Dolichospermum jacuticum (KISELEV) comb. nova basionym: Anabaena jacutica Kiselev, Gosud. Hidrol. Inst., Issled. Morej SSSR 15: 100, 1932.

- Dolichospermum lemmermannii (RICHTER in LEMMERMANN) comb. nova-basionym: Anabaena lemmermannii Richter in LEMMERMANN, Forschungsber. Biol. Stat. Plön 10: 153, 1903.

- Dolichospermum longicellularis (PANKow) comb. nova - basionym: Anabaena spiroides var. longicellularis PANKOW, Limnologova, Berlin, 3(2): 163-172, 1965 [Syn.: Anabaena longicellularis (PANKOW) KoMÁRKOVÁ-LEGNEROVÁ et Eloranta, Algolog. Stud. 67: 125, 1992].

- Dolichospermum macrosporum (KLEBAHN) comb. nova - basionym: Anabaena macrospora KLEBAHN, Flora 80: 269, 1895.

- Dolichospermum maximum (CRONBerg et KomÁreK) comb. nova - basionym: Anabaena maxima Cronberg et Komárek, Nova Hedwigia 78(1/2): 77, 2004.

- Dolichospermum mendotae (TRELEASE) comb. novabasionym: Anabaena mendotae TrelEAse, Trans. Wisconsin Acad. Sci. 7: 123, 1889.

- Dolichospermum mucosum (KomÁrková-LegnerovÁ et Eloranta) comb. nova - basionym: Anabaena mucosa KomÁRKovÁ-Legnerová et Eloranta, Algolog. Stud. 67: 125-126, 1992.

- Dolichospermum nathii (VAsishTA) comb. nova basionym: Anabaena nathii VAsISHTA, Res. Bull. (N.S.) Panjab Univ., 11(I-II): 67, 1960.

- Dolichospermum nygaardii (CRONBERG et KomÁreK) comb. nova - basionym: Anabaena nygaardii Cronberg et KomÁrek, Nova Hedwigia 78: 7778, 2004.

- Dolichospermum perturbatum (HILl) comb. nova - basionym: Anabaena perturbata HiLl, Phycologia 15(1): 67, 1976.

- Dolichospermum planctonicum (BRUNNTHALER) comb. nova - basionym: Anabaena planctonica BrunNThaler, Sitzungsb. K. Akad. Wiss. Wien, mat.-nat., 103(1): 4, 1903

- Dolichospermum pseudocompactum (M. WatANABE) comb. nova - basionym: Anabaena pseudocompacta M. Watanabe, Bull. Nat. Sci. Museum, Ser. B, 22(3): 94, 1996.

- Dolichospermum sigmoideum (NygaARd) comb. nova - basionym: Anabaena sigmoidea NygaArd, Kong. Danske Vidensk. Selsk. Biol. Skr. 7(1): 199, 1949.

- Dolichospermum skujae-laxum (KomÁreK et ZAPOMĚLOVÁ) comb. nova - basionym: Anabaena skujae-laxa KoMÁREK et ZAPOMĚLOVÁ, Fottea 7(1): 27, 2007 [syn.: Anabaena flos-aquae var. laxa Skuja, N. Acta R. Soc. Sci. Upsal., Ser. 4, 16(3): 78, 1956].
- Dolichospermum smithii (KoMÁREK) comb. nova basionym: Anabaena solitaria f. smithii KOMÁREK, Algolog. Studien p. 129, 1958 [Anabaena smithii (KomáReK) M. Watanabe, Bull. Nat. Sci. Mus., ser. B, 18(4): 131, 1992].

- Dolichospermum solitarium (KLEBAHN) comb. nova - basionym: Anabaena solitaria KLEBAHN, Flora 80: 270, 1895.

- Dolichospermum spiroides (KLEBAHN) comb. nova basionym: Anabaena spiroides KLEBAHN, Flora - allg. bot. Ztg. 1895: 268, 1895.

- Dolichospermum torques-reginae (КомÁREK) comb. nova - basionym: Anabaena torques-reginae KomÁreK, Acta Bot. Cubana 19: 14-16, 1984.

- Dolichospermum viguieri (DENIS et FRÉmy) comb. nova - basionym: Anabaena viguieri Denis et FrÉMY, Bull. Soc. Linn. Normandie, Ser. 7, 6: 122,1924

- Dolichospermum werneri(BRUNNTHALER) comb. nova - basionym: Anabaena werneri BRUnNTHALER, Sitzungsb. K. Akad. Wiss. Wien, mat.-nat., 112(1): 292, 1903.

- Dolichospermum zinserlingii (KosinsKaja) comb. nova - basionym: Anabaena zinserlingii Kosinskaja, Russ. Arch. Protistol. 8(3/4): 245, $248,1929$.

\section{Discussion}

This article does not solve the taxonomy of different Dolichospermum species. All up to now described species which evidently belong into the "planktic Anabaena-cluster" according to position in phylogenetic tree (lit. cit.), and/or which correspond morphologically to this characteristical "Anabaena" morphotype with gas vesicles in cells are transferred into the genus Dolichospermum. The listed characteristic morphospecies were taxonomically described by phenotype taxonomy, they are usually well recognizable in natural samples and occur repeatedly in nature. They are all therefore transferred into a new revised genus Dolichospermum.

It is known that particularly the traditional Dolichospermum morphospecies with coiled trichomes described from nature (for review see in KoMÁREK \& ZAPOMĚLOVÁ 2007, 2008) change drastically in cultures (ZAPOMĚLOVÁ et al. 2008; in press). The questions concerning molecular and phenotype variability need therefore further studies. The relationships between different species are not yet definitely solved, but the separation of a special genus is justified and all up to date corresponding and validly described 
planktic Anabaena-species should be transferred into this genetic entity.

Different subclusters of the traditional genus Aphanizomenon (cf. GUGGer et al. 2002b, RAJANIEMI et al. 2005a; Fig. 1) also belong into the large planktic cluster with Dolichospermumstrains. From this point of view, also the planktic Anabaena (= Dolichospermum) cluster is not monophyletic.

Stable morphological markers of Aphanizomenon are unique and distinct in such a degree that its generic separation from Dolichospermum is justifiable. Aphanizomenon itself is also surely heterogeneous (Li et al. 2002, 2003, Rajaniemi et al. 2005a,b, Willame et al. 2006) and various Aphanizomenon-subclusters are distinguishable in the tree (Fig. 1) as isolated generic clusters. These subclusters differ from each other substantially by smaller percentage of similarity and by important and stable phenotype (autapomorphic) characters (structure of trichomes, morphology of terminal cells, facultative formation of gas vesicles, etc.). They are therefore classified in special generic units (Aphanizomenon sensu stricto, Cuspidothrix; RAJANIEMI et al. 2005b, KomÁreK \& KomÁrKovÁ 2006).

A few strains (morphotypes?), the position of which is very unique (RAJANIEMI et al. 2005a: Anabaena compacta), or which differ from this cluster by percentage of 16S rRNA gene similarity distinctly lower than $95 \%$, appeared also within the planktic cluster "Anabaenal Dolichospermum". E.g. according to ZAPOMĚLOVÁ et al. (in press), the strains FM161348 and FM161349 of Anabaena reniformis differ from the Dolichospermum cluster only by about $92 \%$ 16S rRNA gene similarity, and these strains form special group containing also Anabaena kisseleviana and Anabaena aphanizomenoides (strain FM161350). The phenotype difference from other Dolichospermum species (form and position of akinetes in trichomes, morphology of end cells) is not doubtless, but it is separated in such a degree that the taxonomic classification in a special genus Sphaerospermum is proposed (ZAPOMĚLOVÁ et al. , in press). However, the final taxonomic position of several other types of "planktic Anabaenas" is still unsolved, but this our paper should be the basis for next studies.

The proposed limit for separation of different cyanobacterial genera is $95 \%$ of $16 \mathrm{~S}$ rRNA gene similarity (WAYNE et al. 1987,
StaCKebrand \& Goebel 1994). This limit cannot be applied obligatorily. In nature sharp numerical limits (even correctly calculated) never exist, and also in this case the percentage of 16S rRNA gene similarity can serve only as one of important criteria, which can be (and should be) applied in complex in connection with other valuable genetically important and stable characters. However the autapomorphic phenotypic marker should also be applied in generic descriptions. The combined, special type of metameric structure of solitary floating trichomes, with paraheterocytic formation of akinetes and obligatory presence of gas vesicles in cells represents there special characters in Dolichospermum.

\section{Acknowledgement}

The authors are indebted to all who helped during the elaboration of this study and read critically this manuscript, particularly to J. Komárková and E. Zapomělová. The correction of the genus Dolichospermum was possible only on the basis of studies of I. Iteman (Paris), M. Gugger (Paris), P. Wacklin-Rajaniemi (Helsinki), R. Willame (Liège), E. Zapomělová (České Budějovice) and with the support of L. Hoffmann (Luxembourg) and K. Sivonen (Helsinki). All these authors and their collaborators have the largest merit on the recognition of heterogeneity of the traditional genus Anabaena. This manuscript was evoked by the need of validation of the genus Dolichospermum in the frame of preparation of the third part of Cyanobacteria for the compendium Süsswasserflora von Mitteleuropa. The manuscript was prepared in the frame of the grant GAASCR No IAA600050704.

\section{References}

Bornet, E. \& Flahault, C. (1886-1888): Revision des Nostocacées heterocystées. - Ann. Sci. Nat.Bot., 7 ser., 3: 323-381, 4: 343-373, 5: 51-129, 7: 171-262.

Geitler, L. (1932): Cyanophyceae. - In: RABEnhorst's Kryptogamenflora von Deutschland, Österreich und Schweiz 14. - 1196 pp., Akad. Verlagsges., Leipzig.

Greuter, W., McNeill, J., Barrie, F.R., Burdet, H.-M., Demoulin, V., Filgueiras, T.S., Nicholson, D.H., Silva, P.C., Skog, J.E., Trehane, P., Turland, N.J. \& Hawksworth, D.L. (eds.) (2000): International code of botanical nomenclature (St Louis code), adopted by the sixteenth international botanical congress, St. Louis, Missouri, July-August 1999. - Koeltz Scientific Books, Königstein.

Gugger, M., Lyra, C., Henriksen, P., Couté, A., 
Humbert, J.-F. \& Sivonen, K. (2002a): Phylogenetic comparison of the cyanobacterial genera Anabaena and Aphanizomenon. Internat. J. Syst. Evol. Microbiol. 52: 1-14.

Gugger, M., Lyra, C., Suominen, I., Tsitko, I., Humbert, J.-F., SAlkinoja-SAlonen, M. \& Sivonen, K. (2002b): Cellular fatty acids as chemotaxonomic markers of the genera Anabaena, Aphanizomenon, Microcystis, Nostoc and Planktothrix (Cyanobacteria). - Internat. J. Syst. Evol. Microbiol. 52: 1007-1015.

Hoffmann, L., KomÁrek, J. \& KAŠTovskÝ, J. (2005): System of cyanoprokaryotes (cyanobacteria) state in 2004. - Algolog. Stud. 117 (Cyanobact. Res. 6): 95-115.

Iteman, I., Rippka, R., Tandeau de Marsac, N. \& Herdman, M. (2002): rDNA analyses of planktonic heterocystous cyanobacteria, including members of the genera Anabaenopsis and Cyanospira. - Microbiology 148: 481496.

KomÁreK, J. \& Komárková, J. (2006): Diversity of Aphanizomenon-like cyanobacteria. - Czech Phycology 6: 1-32.

KomÁreK, J. \& ZAPOMĚLovÁ, E. (2007): Planktic morphospecies of the cyanobacterial genus Anabaena $=$ subg. Dolichospermum - 1. part: coiled types. - Fottea 7: 1-31.

KomÁreK, J. \& ZAPOMĚLovÁ, E. (2008): Planktic morphospecies of the cyanobacterial genus Anabaena $=$ subg. Dolichospermum -2 . part: straight types. - Fottea 8: 1-14.

Li, R., Carmichael, W.W., Liu, Y. \& Watanabe, M.M. (2000): Taxonomic re-evaluation of Aphanizomenon flos-aquae NH-5 based on morphology and $16 \mathrm{~S}$ rRNA sequences. Hydrobiology 438: 99-105.

Li, R., Carmichael, W. W. \& Pereira, P. (2003). Morphological and 16S rRNA gene evidence for reclassification of the paralytic shellfish toxin producing Aphanizomenon flos-aquae LMECYA 31 as Aphanizomenon issatschenkoi (Cyanophyceae). - J. Phycol. 39: 814-818.

Oren, A. \& Tindal, B.J. (2005): Nomenclature of the cyanophyta/cyanobacteria/ cyanoprokaryotes under the Intrnational Cone of Nomenclature of Prokaryotes. - Algolog. Stud. 117: 39-52.

Rajaniemi, P., Hrouzek, P., Kaštovská, K. , Willame, R., Rantala, A., Hoffmann, L., Komárek, J. \& Sivonen, K. (2005a): Phylogenetic and morphological evaluation of the genera Anabaena. Aphanizomenon, Trichormus and Nostoc (Nostocales, Cyanobacteria). - Internat. J. Syst. Ecol. Microbiol. 55: 11-26.

Rajaniemi, P., Komárek, J., Hrouzek, P., Willame, R., Kaštovská, K., Hoffmann, L. \& Sivonen, K. (2005b): Taxonomic consequences from the combined molecular and phenotype evaluation of selected Anabaena and Aphanizomenon strains. - Arch. Hydrobiol./Algolog. Stud. 117 (Cyanobacterial Research 6): 371-391.

Ralfs, J. (1850): On the Nostochineae. - Annals Magazine nat. Hist. 5.

Stackebrand, E. \& Goebel, B. M. (1994). Taxonomic Note: A for place for DNA-DNA reassociationand $16 \mathrm{~S}$ rRNA sequence analysis in the present species definition in Bacteriology. - Int. J. Syst. Bacteriol. 44: 846-849.

Walsby, A.E. (1972): Structure and function of gas vacuoles. - Bact. Rev. 36: 1-32.

WALSBY, A.E. (1978): The gas vesicles of aquatic prokaryotes. - In: STANIER, R.Y.; Rogers, H.J. \& Ward, J.B. (eds): Symb. Soc. Gen. Microbiol. 28. - pp. 327-357, Univ. Press, Cambridge.

Walsby, A.E. (1981): Cyanobacteria: planktonic gas vacuolate forms. - In: STARR, M.P. et al. (eds): The Prokaryotes, Vol. 1. - pp. 224-235, Springer Verlag, Berlin-Heidelberg-New York.

Wayne, L.G., Brenner, D.J., Colwell, R.R., Grimont, P.A.D., Kandler, O., Krichevsky, M.I., Moore, W.E.C., Murray, R.G.E., Stackebrand, E., STARr, M.P. \& TRÜPER, H.G. (1987): Report of the ad hoc committee on reconciliation of approaches to bacterial systematics. - Int. J. Syst. Bacteriol. 37: 463-464.

Willame, R., Boutte, C., Grubisic, S., Wilmotte, A., Komárek, J. \& Hoffmann, L. (2006): Morphological and molecular characterisation of planktonic cyanobacteria from Belgium and Luxembourg. - J.Phycol. 42: 1312-1332.

ZapomělovÁ, E., Řeháková, K., Znachor, P. \& KomÁrkovÁ, J. (2007): Morphological diversity of coiled planktonic types of the genus Anabaena (Cyanobacteria) in natural populations - taxonomic consequences. Cryptogamie Algologie 28: 353-371.

ZapomĚlová, E. , HrouzeK, P., ŘehÁKovÁ, K., ŠABACKÁ, M., Stibal, M., Caisová, L., KomÁrková, J. \& LuKEŠOvÁ, A. (2008): Morphological variability in selected heterocytous cyanobacterial strains as a response to varied temperature, light intensity and medium composition. - Folia Microbiologica 53: 333-341.

Zapomělová, E., Jezberová, J., Hrouzek, P., Hisem, D., ŘehÁková, K. \& Komárková, J. (in press): Polyphasic characterisation of three strains of Anabaena reniformis and Aphanizomenon aphanizomenoides (Cyanobacteria) and their re-classification to Sphaerospermum gen. nov. (incl. Anabaena kisseleviana). - J. Phycol.

(C) Czech Phycological Society

Received December 31, 2008

Accepted February 15, 2009 